\title{
VÁKUUM MÉRÉSÉRE ALKALMAS RENDSZER FEJLESZTÉSE HŐVEZETÉSEN ALAPULÓ ÉRZÉKELŐ ÉS ALACSONY KÖLTSÉGÛ́ BEÁGYAZOTT RENDSZER FELHASZNÁLÁSÁVAL
}

\section{DEVELOPMENT OF A PRESSURE MEASURING UNIT BASED ON A THERMAL CONDUCTIVITY GAUGE AND A LOW COST EMBEDDED SOLUTION FOR MID-RANGE VACUUM APPLICATIONS}

\author{
Fekete Albert-Zsombor ${ }^{1}$, Jakab-Farkas László ${ }^{2}$ \\ ${ }^{1,2}$ Sapientia - Erdélyi Magyar Tudományegyetem, Marosvásárhelyi Kar, 540485, \\ Románia, Marosvásárhely, Segesvári út 1C; Tel. +40-766-649950, e-mail: \\ 1zsombor.fekete@tetronic.ro, ${ }^{2}$ jflaci@ms.sapientia.ro.
}

\begin{abstract}
The study presents the development of a pressure measuring unit based on a Pirani gauge and a dedicated embedded system, incorporating a simple, low cost practical solution for reducing significantly the various measurement altering factors, such as drifts and offsets. This is achieved by eliminating the conventional differential analogue signal processing stage and by replacing it with a high resolution analog to digital converter. Therefore the goal was to minimize the number of the electronic components whose operation is influenced by the variation of the ambient temperature.
\end{abstract}

Keywords: vacuum pressure, thermal conductivity gauge, low cost embedded solution, high resolution analog to digital converter, network connectivity.

\section{Összefoglalás}

A tanulmány egy hővezetésen alapuló érzékelő és egy dedikált beágyazott rendszer segítségével megvalósított nyomásmérő rendszer tervezési lépéseit ismerteti, amely egy egyszerü, alacsony költségü gyakorlati megoldást biztosít a mérést befolyásoló drift és ofszet tényezők jelentős lecsökkentésére. A javasolt megoldás a hagyományos analóg differenciális jelfeldolgozó egységnek egy nagy felbontású analóg-digitális átalakítóval történő helyettesítését feltételezi. A kitüzött cél minimálisra csökkenteni azon elektronikai alkatrészek számát, amelyeknek működését befolyásolja a környezeti hőmérséklet változása.

Kulcsszavak: vákuum-nyomás, hövezetésen alapuló érzékelö, alacsony költségü beágyazott rendszer, nagy felbontású analóg-digitális átalakító, hálózati kapcsolat.

\section{Bevezetés}

A vákuum berendezések egyik legfontosabb eleme az evakuálási rendszer, melynek rendellenes müködése a berendezés nem kívánt leállásához és esetenként a használt szivattyúk végérvényes meghibásodásához vezethet. Ennek elkerülése érdekében, a vákuum-berendezések [2] müködtetésének egyik legfontosabb feladata a nyomás megfelelő mérése és a vákuumszint felügyelete. 


\section{Hővezetésen alapuló érzékelő}

A turbomolekuláris és a rotációs szivattyúk között lévő vákuumvonalak esetében rendszerint Pirani-nyomásmérőt alkalmaznak.

Az érzékelő működése a hőátadási és hővezetési tényezők nyomásfüggésén alapszik [1]. Az érzékelö fütött izzószálának hőmérséklete egy egyensúlyi hőmérséklet, amelyet a termelt és leadott hőmennyiségek egyensúlya határoz meg. A gáz hővezető képessége csökken a nyomáscsökkenéssel, így megváltozik a termikus egyensúlyi hőmérséklet és ezáltal a fütőszál ellenállása is. Ez az ellenállás változás a nyomásváltozásnak tulajdonítható, ezért indirekt módon jelzi a nyomás értékét [1,4].

A mérőeszköz viszonylag széles nyomástartományban (5 - $1 \cdot 10^{-4}$ Torr) használható. Az egyszerü és robusztus felépítésének köszönhetően minimális karbantartást igényel.

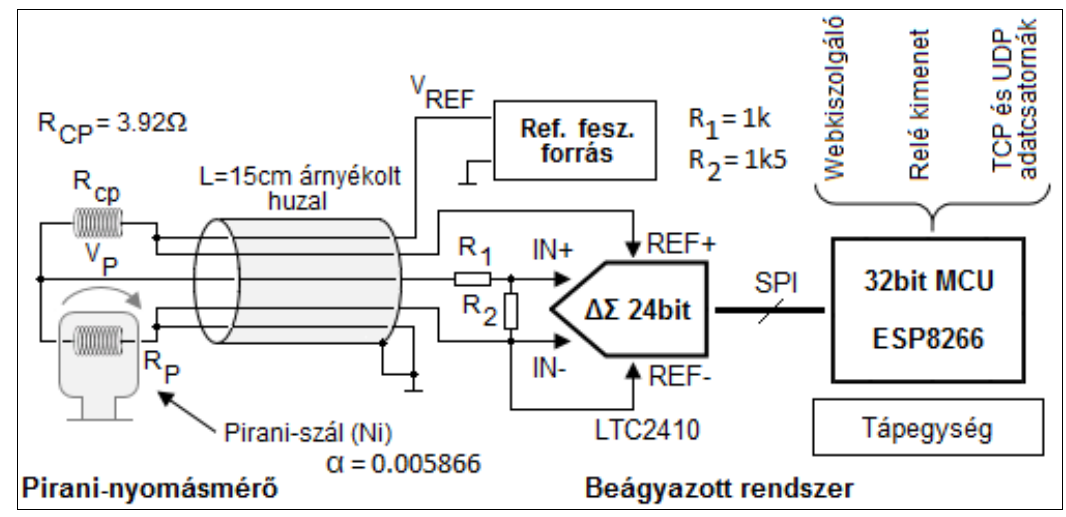

1. ábra. A méröáramkör és a beágyazott rendszer egyszerüsített tömbrajza

\section{A beágyazott rendszer}

A cél egy alacsony költségü beágyazott rendszer (2. ábra) kialakítása volt, amely közvetlenül kapcsolódik a FAN Pirani mérőfej nikkel izzószálára $\left(\mathrm{R}_{\mathrm{P}}\right)$ egy LTC2410 szigma-delta típusú [6] analóg-digitális átalakítóval (ADC). Ez a megközelítés (1. ábra) kiküszöböli a hagyományos differenciálerősítő fokozatot, minimalizálva az aktív komponensek számát, amelyek ofszetet és driftet okozhatnak. Az átalakító hibahatára ebben az esetben csak 2.5ppm, míg a maximális bemeneti hőmérsékleti feszültség drift $10 \mathrm{nV} / \mathrm{C}^{0}[6]$.

$\mathrm{Az}$ ADC egy szinkron soros interfészen (SPI) keresztül egy 80 MIPS-es, 32 bites ESP8266 típusú mikrovezérlőhöz (MCU) [5] csatlakozik. A mintavételi idő 500ms, és minden átalakítást az MCU kezdeményez.

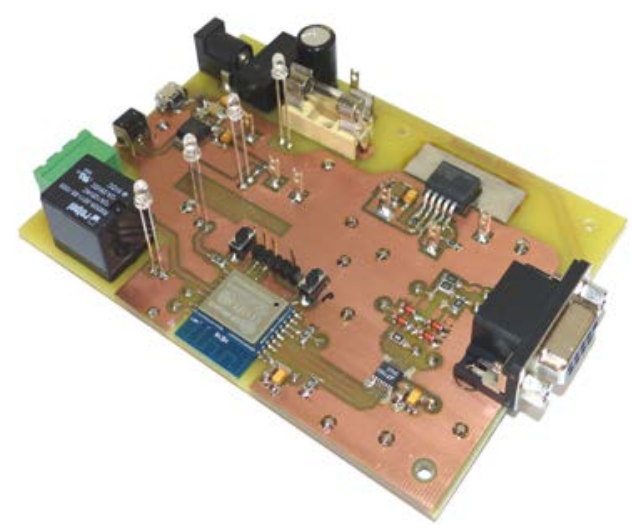

2. ábra. A beágyazott rendszer prototípusa

A beágyazott rendszer vezeték nélküli hálózati kapcsolódást biztosít, lehetővé téve TCP és UDP adatcsatornák révén a távoli hozzáférést [2]. 


\section{Mérések és kalibráció}

A kalibrálási eljárást egy Pfeiffer Vacuum PKR251 [7] típusú teljes tartományú nyomásmérővel végeztük, melynek globális pontossága $\pm 30 \%$. Mindkét mérőeszközt egy szabályozható nyomású vákuumkamrához illesztettük. A méréseket $\mathrm{q}_{\mathrm{N} 2}=4$ SCCM és $\mathrm{q}_{\mathrm{Ar}}=6 \mathrm{SCCM}$ hozamokkal kialakult gázkeverék, valamint 16bittes ADC felbontás mellett végeztük el. A különböző gázok hőkapacitása és hővezetési képessége eltérő [3], ezért a kalibrálási folyamatot célszerű a használt gázok jelenlétében végezni.

Figyelembe véve az ellenállás hőmérséklettől való függését, valamint a bemutatott áramkör feszültségegyenleteit, megbecsülhető a fütőszál hőmérséklete (1) és a hőmérsékletváltozás felbontása (3) egy adott egyensúlyi állapotban.

$$
T=\frac{\frac{V_{P} \cdot R_{C P}}{V_{R E F}-V_{P}}+R_{P}^{\prime}\left(\alpha \cdot T^{\prime}-1\right)}{\alpha \cdot R_{P}^{\prime}},
$$

ahol az $\mathrm{R}_{\mathrm{p}}^{\prime} \quad(3,72 \Omega)$ a Pirani-szál referenciaellenállása $\mathrm{T}^{\prime}=30 \mathrm{C}^{\mathrm{O}}$-on, $\alpha$ a nikkel ellenállás hőmérsékleti koefficiense, míg $\mathrm{V}_{\mathrm{P}}$ a feszültségesés az izzószálon (2)

$$
V_{P}=\frac{A D C \cdot 0.5 \cdot V_{R E F} \cdot\left(R_{1}+R_{2}\right)}{R_{2} \cdot\left(2^{16}-1\right)} .
$$

A (3)-as összefüggés értelmében a felbontás növelhetö a $V_{\mathrm{REF}}$ növelésével.

$$
\Delta T=\Delta V_{P} \cdot \frac{R_{C P}}{V_{R E F} \cdot \alpha} \cdot \frac{1}{\left(1-\frac{V_{P}}{V_{R E F}}\right)^{2}}
$$

Gyakorlati úton meghatároztuk a $\mathrm{V}_{\mathrm{REF}}$ értékét úgy, hogy a nyomástartomány alsó részén az $\mathrm{AD}$ konverzió kvantuma $\Delta \mathrm{p}=1.5 \cdot 10^{-5}$ Torr nyomásváltozásnak feleljen meg. Ezáltal a $4 \cdot 10^{-4}$ Torr értékü végvákuum és a fent leírt eljárással kapott $194 \mathrm{mV}$-os referenciafeszültség mellett az izzószál hőmérséklete (1) $95^{\circ} \mathrm{C}$. Olajjal tömített rotációs szivattyúk esetében az olajgőzök a meleg Pirani-szál felületén lerakodnak, megváltoztatva a hőátadási paramétereit, ezért ajánlatos a lehető legalacsonyabb hőmérsékleten müködtetni.

\begin{tabular}{|c|c|c|c|c|}
\hline $\begin{array}{l}\text { Nyomás- tar- } \\
\text { tomány [Torr] }\end{array}$ & $\begin{array}{c}\text { Kalibrációs függvények: } \mathrm{p}=\mathrm{f}(\mathrm{x}) \text { [Torr], ahol } \\
\mathrm{x}=\mathrm{ADC} \text { érték }- \text { statikus ofszet }\end{array}$ & $\begin{array}{c}\text { Át- } \\
\text { laghi } \\
\text { ba } \\
{[\%]}\end{array}$ & $\sigma^{2}[\%]$ & $\begin{array}{l}\text { Felbontás } \\
\text { [Torr] }\end{array}$ \\
\hline $2 \div 1$ & $7.8046 \cdot 10^{-4} x^{2}-6.5190 \cdot 10^{-2} x+2.5216$ & 1.25 & 0.74 & $5.64 \cdot 10^{-2}$ \\
\hline $1 \div 8 \cdot 10^{-1}$ & $-9.5460 \cdot 10^{-3} \mathrm{x}+1.4252$ & 0.25 & 0.01 & \multirow{4}{*}{$8.41 \cdot 10^{-3}$} \\
\hline $8 \cdot 10^{-1} \div 6 \cdot 10^{-1}$ & $-5.1364 \cdot 10^{-3} x+1.1067$ & 0.26 & 0.05 & \\
\hline $6 \cdot 10^{-1} \div 3 \cdot 10^{-1}$ & $1.0198 \cdot 10^{-5} x^{2}-5.5330 \cdot 10^{-3} x+1.0323$ & 0.18 & 0.01 & \\
\hline $3 \cdot 10^{-1} \div 1 \cdot 10^{-1}$ & $4.5231 \cdot 10^{-7} \mathrm{x}^{2}-7.4903 \cdot 10^{-4} \mathrm{x}+4.0840 \cdot 10^{-1}$ & 0.48 & 0.03 & \\
\hline $1 \cdot 10^{-1} \div 7 \cdot 10^{-2}$ & $1.0020 \cdot 10^{-7} x^{2}-2.7747 \cdot 10^{-4} x+2.4969 \cdot 10^{-1}$ & 0.08 & 0.01 & \multirow{3}{*}{$7.30 \cdot 10^{-5}$} \\
\hline $7 \cdot 10^{-2} \div 4 \cdot 10^{-2}$ & $3.6922 \cdot 10^{-8} \mathrm{x}^{2}-1.4581 \cdot 10^{-4} \mathrm{x}+1.8102 \cdot 10^{-1}$ & 0.24 & 0.02 & \\
\hline $4 \cdot 10^{-2} \div 1 \cdot 10^{-2}$ & $4.4449 \cdot 10^{-9} x^{2}-3.7522 \cdot 10^{-5} x+8.9687 \cdot 10^{-2}$ & 1.35 & 0.79 & \\
\hline $1 \cdot 10^{-2} \div 3 \cdot 10^{-3}$ & $6.8013 \cdot 10^{-10} x^{2}-1.0591 \cdot 10^{-5} x+4.1463 \cdot 10^{-2}$ & 0.37 & 0.05 & \multirow{2}{*}{$5.03 \cdot 10^{-6}$} \\
\hline $3 \cdot 10^{-3} \div 1 \cdot 10^{-3}$ & $-1.247 \cdot 10^{-8} \mathrm{x}^{2}+1.3696 \cdot 10^{-4} \mathrm{x}-3.7305 \cdot 10^{-1}$ & 1.47 & 0.81 & \\
\hline $1 \cdot 10^{-3} \div 6 \cdot 10^{-4}$ & $-8.9454 \cdot 10^{-6} x+5.3825 \cdot 10^{-2}$ & 0.53 & 0.06 & \multirow{2}{*}{$1.51 \cdot 10^{-5}$} \\
\hline $6 \cdot 10^{-4} \div 4 \cdot 10^{-4}$ & $-6.9886 \cdot 10^{-8} x+5.3825 \cdot 10^{-2}$ & 0.51 & 0.01 & \\
\hline
\end{tabular}

1. táblázat. Nyomás kalibrációs függvények FAN Pirani érzékelö számára 194mV-os referenciafeszültség, 16bittes felbontás, valamint Ar és $N_{2}$ gázkeverék használata esetében 
Adott rendszerparaméterek mellett, a 12 részre osztott nyomástartomány mindenikében első, vagy másodrendü polinomfüggvénnyel közelítettük meg az AD konverzió kísérletileg meghatározott eredményét a nyomás függvényében (1. táblázat).

Meghatároztuk a beágyazott rendszeren implementált függvények kiszámításának pontosságát, valamint a különböző nyomástartományokban érvényes felbontásokat. Az átlaghiba, valamint a szórásnégyzet $\left(\sigma^{2}\right)$ a számolt nyomás és a kalibráló mérőeszköz által mért nyomás közti eltérést adják meg. A kapott eredményeket az 1. táblázat és a 3. ábra tartalmazza.

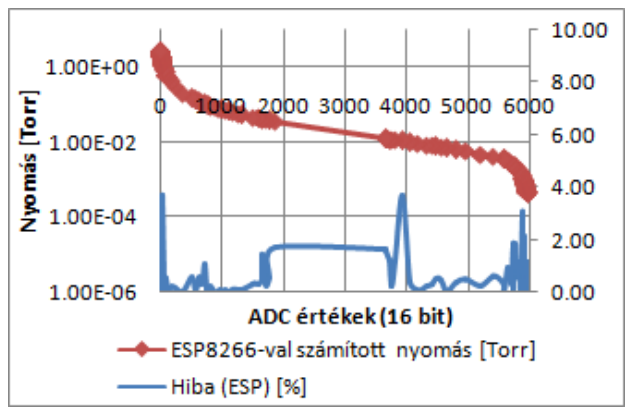

3. ábra. ESP8266 típusú beágyazott rendszerrel számolt nyomás és az elért pontosság

\section{Szoftver kialakítás}

Bár az MCU egy 32 bites architektúrát tartalmaz, a fejlesztési környezet úgy a double, mint a float változótípust 7 tizedesre korlátozza. Ez azt eredményezi, hogy a különböző kalibrációs függvények pontossága jelentősen lecsökken.

A javasolt megoldás egy dedikált könyvtár [8] használatát feltételezi, amely a tizedesek számát 16-ra növeli. Ezzel arányosan megemelkednek a rendszerkövetelmények is. A maximális tapasztalt végrehajtási idő $4 \mathrm{~ms}$, amely $0.8 \%$-a a mintavételi időnek.

\section{Következtetések}

A kifejlesztett rendszer egy viszonylag egyszerü és alacsony költségü megoldást kínál Pirani nyomásmérők működtetésére. Lehetőség nyílik a müködési paraméterek optimalizálására az alkalmazási terület és a nyomástartomány ismeretében.

Ugyanakkor létfontosságú biztonsági elemként is szolgál, amely képes érzékelni a nyomásvesztést és az evakuálási rendszer egyes müködési rendellenességeit.

\section{Köszönetnyilvánítás}

Köszönet illeti Szöllösi Istvánt és a Thin Solid Films Research Group (TSFRG) munkatársait a fejlesztési munka során nyújtott segítségükért.

\section{Szakirodalmi hivatkozások}

[1] P. K. Weng and J. S. Shie: Micro-Pirani vacuum gauge. Review of Scientific Instruments, vol. 65, pp. 492-499, 1994.

[2] A.-Z. Fekete, A. Kelemen, and L. JakabFarkas: Multilevel Distributed Embedded System for Control of the DC Magnetron Sputtering Process. Acta Universitatis Sapientiae Electrical and Mechanical Engineering, vol. 9, pp. 43-55, 2017.

[3] K. Toshio, H. Tadahiko, N. Yohta, and T. Hiroyuki: Sensitivity Coefficients of Pirani Gauge for Various Atoms and Molecules Japanese Journal of Applied Physics, vol. 37, p. 369, 1998.

[4] T. Brun, D. Mercier, A. Koumela, C. Marcoux, and L. Duraffourg: Silicon nanowire based Pirani sensor for vacuum measurements. Applied Physics Letters, vol. 101, p. 183506, 2012.

[5] Espressif: ESP-WROOM-02. ESP8266 adatlap, 2017 (verzió: 2.5).

[6] Linear Technology: 24-Bit No Latency $\Delta \Sigma^{\mathrm{TM}}$ $A D C$ with Differential Input and Differential Reference. LTC2410 adatlap, 2000 (REV A).

[7] Pfeiffer Vacuum: Compact Full Range ${ }^{\mathrm{TM}}$ Gauge. PKR251 adatlap, 2008-04.

[8] N. Gammon: BigNumber könyvtár: https://github.com/nickgammon/BigNumber (2018.02.10). 